\title{
MAKNA ASPEK FISIK DAN NON FISIK DALAM TATANAN RUANG HUNIAN MASYARAKAT DI DATARAN TINGGI KEC. PONCOKUSUMO, KAB. MALANG
}

\author{
Debby Budi Susanti \\ Dosen Prodi Arsitektur, Fak. Teknik Sipil dan Perencanaan, ITN Malang \\ e-mail: budisusantidebby@gmail.com \\ Gaguk Sukowiyono \\ Dosen Prodi Arsitektur, Fak. Teknik Sipil dan Perencanaan, ITN Malang \\ e-mail: gaguksukowiyono@yahoo.com
}

\begin{abstract}
ABSTRAK
Penelitian ini berupaya untuk menggali makna yang ada dalam hunian masyarakat di dataran tinggi berdasarkan aspek fisik dan non fisik yang ditampilkan pada rumah tinggal masyarakat di kawasan Kecamatan Poncokusumo, Kabupaten Malang. Kecamatan Poncokusumo merupakan kawasan hinterland Kota Malang yang berbatasan langsung dengan kawasan Desa Ngadas, Tengger. Dengan posisi yang demikian masyarakat di kawasan Kecamatan Poncokusumo mendapat pengaruh dari dua budaya, yaitu budaya dari masyarakat Kota Malang dan budaya dari suku Tengger Bromo. Sehingga penataan hunian masyarakat di kawasan Kecamatan Poncokusumo menyesuaikan dengan tradisi dan budaya masyarakat dari dua kawasan yang berdekatan dengan wilayahnya, yaitu Kota Malang dan Suku Tengger Bromo.
\end{abstract}

Kata kunci : hunian, ruang, aspek fisik dan non fisik

\begin{abstract}
This study seeks to explore the meaning that exists in highland community housing based on physical and non-physical aspects that are displayed in community homes in the District of Poncokusumo, Malang Regency. Poncokusumo Subdistrict is a hinterland area of Malang City which is directly adjacent to the Ngadas Village area, Tengger. With such a position the people in the Poncokusumo District area are influenced by two cultures, namely the culture of the people of Malang City and the culture of the Tengger Bromo tribe. So that the arrangement of community dwelling in the Poncokusumo District area adjusts to the traditions and culture of the people of the two areas that are close to the area, namely Malang City and the Tengger Bromo Tribe.
\end{abstract}

Keywords : occupancy, space, physical and non-physical aspects 


\section{PENDAHULUAN}

Pada masyarakat modern saat ini, faktor yang menjadi kendala dalam pemenuhan kebutuhan yang berupa rumah tempat tinggal adalah faktor keterbatasan lahan yang pada akhirnya berdampak pada semakin tingginya harga lahan. Hal tersebut terutama terjadi di kawasan perkotaan. Berbeda halnya dengan di kawasan pedesaan. Pada kawasan pedesaan, sebagian besar lahan digunakan sebagai lahan pertanian atau perkebunan yang memang menjadi sumber mata pencaharian utama masyarakat di kawasan pedesaan. Lingkungan alam di kawasan pedesaan cenderung tidak banyak mengalami perubahan, tidak seperti di kawasan perkotaan yang sudah semakin padat dengan bangunan. Sehingga faktor utama yang berpengaruh pada hunian di kawasan pedesaan adalah karakter lingkungan alam dan iklim setempat. Demikian juga dengan kawasan permukiman pedesaan yang berada di daerah dataran tinggi yang biasanya memiliki kondisi iklim yang cukup ekstrim, dengan suhu udara yang relatif rendah dan kelembaban udara yang lebih tinggi bila dibandingkan dengan di kawasan perkotaan.

Berpijak dari kondsi tersebut, pada penelitian ini berupaya untuk menggali aspek fisik dan non fisik yang terjadi pada tatanan ruang huniannya. Aspek fisik dan non fisik tersebut yang kemungkinan menjadi karakter dan kekhasan lingkungan binaan yang ada di kawasan permukiman masyarakat di daerah dataran tinggi. Upaya manusia untuk beradaptasi dengan lingkungan fisik dan iklim di sekitarnya, serta kondisi harfiah manusia sebagai maklhuk sosial yang membutuhkan wadah untuk berinteraksi dengan masyarakat di sekitarnya menjadi fokus dari penelitian ini untuk meneliti makna dari setiap elemen desain arsitektural yang ada pada sebuah hunian. Setiap elemen interior yang ada dalam sebuah hunian merupakan wujud dari desain arsitektural penghuni rumah yang dapat diamati dari elemen fisik dan non fisik yang ada. Aspek fisik dapat diamati secara langsung oleh setiap orang melalui elemen interior dan eksterior yang ada di dalam rumah dan lingkungan sekitar hunian. Sedangkan aspek non fisik bisa diamati berdasarkan aktifitas rutin dan budaya pemilik atau penghuni rumah, bahkan tidak menutup kemungkinan bisa juga diamati berdasarkan simbol atau elemen dekoratif penanda ruang. Manusia sebagai makhluk yang berbudaya, mengandung pengertian bahwa manusia menciptakan budaya dan kemudian kebudayaan memberikan arah dalam hidup dan tingkah laku manusia. Dalam kebudayaan tercakup hal-hal bagaimana tanggapan manusia terhadap dunianya dan lingkungan masyarakatnya. Seperangkat nilai yang menjadi landasan untuk menentukan sikap terhadap dunia luarnya, bahkan untuk mendasari langkah-langkah kegiatan yang hendak dan harus dilakukan sehubungan dengan kondisi alam maupun pola hidup kemasyarakatannya. Pembentukan suatu lingkungan permukiman pada dasarnya sangat ditentukan oleh berbagai faktor, diantaranya adalah budaya masyarakat setempat.

PAWON: Jurnal Arsitektur, Nomor 01 Volume IV, Bulan Januari-Juni Tahun 2020, ISSN 2597-7636 
Bagaimana individu berhubungan dengan keluarga dan lingkungan sekitarnya sudah tentu berbeda antara satu budaya dengan budaya lainnya, selanjutnya bagaimana ruang itu ditata dan dirancang sangat tergantung pada pandangan hidup masing-masing (Dansby, 1993: 137). Salah satu bagian yang penting untuk diketahui dalam hubungan antara manusia dengan lingkungannya adalah pemahaman tentang bagaimana ruang diorganisasikan tergantung pada tujuan manusia itu sendiri (Aspinall, 1993: 337). Dalam perwujudan tatanan ruang sebuah hunian berbagai hal terkait diantaranya kondisi fisik alami lingkungan, kondisi fisik lingkungan binaan, budaya, norma, tradisi.

\section{TINJAUAN PUSTAKA}

\section{a. Kajian Teoritik Tentang Hunian}

Tatanan ruang ini merupakan ekspresi dari lingkungan sosial dan budaya bermukim masyarakatnya. Sebagai contoh bagaimana tatanan ruang permukiman masyarakat tradisional, yang biasanya menerapkan kaidah-kaidah tersendiri dalam pengaturan gubahan ruang dan massa bangunannya, mengikuti alam pikir atau kosmologi yang dianutnya. Hal ini tercermin dalam pengaturan tata letak bangunan yang pada umumnya disesuaikan dengan aturan hirarki dan fungsi-fungsinya. Kaidah-kaidah teoritik tatanan spasial (spatial order) secara aplikatif biasanya diterapkan pada permukiman yang direncanakan dengan baik (well planned), apakah itu permukiman tradisional maupun permukiman urban. Pada permukiman yang terencana, biasanya telah diterapkan aturan tatanan ruang baku secara teoritis dalam perencanaannya. Lain halnya pada kawasan permukiman padat yang tidak terencana (unplanned), pola ruang atau tatanan ruang terkadang dapat terjadi dengan sendirinya akibat adanya prinsip-prinsip aturan sebagai hasil kesepakatan dan interaksi antarwarganya. Walaupun tak terencana dan sulit untuk dijelaskan, tetapi dapat dilihat bahwa tatanan tersebut merupakan proses pengembangan permukiman yang pada dasarnya memiliki sifat keruangan yang secara arsitektural dapat dipahami. Tatanan Ruang adalah wujud struktural dan pola pemanfaatan ruang yang mewujudkan identitas dan orientasi bangunan rumah, yang meliputi ruang dalam dan ruang luar, serta fungsi ruang (Schulz, 1985). Menurut Yunus (1987), permasalahan permukiman perkotaan menyangkut hal-hal yang berkaitan dengan upaya penyediaan air bersih, sistem pembuangan sampah, sistem pembuangan kotoran, air limbah, tata bangunan, saluran air hujan, penanggulangan bahaya kebakaran, serta pencemaran air, udara, dan tanah.

\section{b. Kajian Aspek Fisik}

Kondisi lingkungan fisik sangat dipengaruhi oleh pola perilaku manusia penghuninya, terutama pada lingkungan binaan yang terbentuk. Walaupun

PAWON: Jurnal Arsitektur, Nomor 01 Volume IV, Bulan Januari-Juni Tahun 2020, ISSN 2597-7636 
selanjutnya kondisi lingkungan binaan yang ada yang kemudian membentuk pola perilaku manusia generasi penerus berikutnya sebagai upaya mereka untuk menyesuaikan atau beradaptasi dengan lingkungan. Sebuah kesalahan pada masalah pembangunan lingkungan binaan merupakan sebuah permasalahan yang akan terjadi terus menerus dan merupakan sebuah lingkaran yang saling berkaitan satu sama lain dan sulit untuk dicari cara penyelesaiannya.

Kondisi termal dalam bangunan ditentukan oleh kinerja termal dari bangunan dan kondisi iklim. Kondisi tersebut disebabkan oleh adanya perpindahan panas di antara keduanya untuk mencapai kondisi yang seimbang (heat balance), sedangkan hantaran termal antara bangunan dengan lingkungan tergantung pada sifat panas dari material bangunan. Indonesia merupakan negara yang beriklim tropis lembab. Pola persebaran pemukiman penduduk dipengaruhi oleh keadaan iklim, keadaan tanah, tata air, topografi dan ketersediaan sumber daya alam yang terdapat di wilayah tersebut. Tidak hanya pola tradisi masyarakat yang mempengaruhi pola tatanan pemukiman masyarakat, tetapi iklim dan kondisi geografi setempat juga turut mempengaruhi kondisi pemukiman penduduknya.

Karakteristik iklim tropis lembab mempunyai derajat kelembaban dan curah hujan yang tinggi. Dampak dari kondisi tersebut adalah banyak terdapat bukaan dan naungan berupa sosoran. Sepanjang tahun mempunyai temperatur rata-rata yang tinggi, sehingga memepengaruhi bangunan mempunyai bukaan yang mempertimbangkan aliran udara. Kondisi tersebut berhubungan dengan diurnal yang rendah ser $8^{\circ} \mathrm{C}$, akibat variasi temperatur yang rendah. Radiasi matahari bervariasi dengan kondisi sering berawan. Tujuan dari perancangan di daerah tropis lembab adalah mereduksi temperatur internal, memaksimalkan ventilasi untuk efektifitas evaporasi, proteksi terhadap sinar matahari, hujan dan serangga.

\section{c. Kajian Aspek Non Fisik}

Kebudayaan sebagai suatu kompleks aktifitas manusia yang berpola, menciptakan suatu sistem sosial bagi masyarakat yang berupa wadah untuk menghasilkan benda-benda pakai dan karya seni, berbentuk nyata sebagai obyek riil, seperti bangunan rumah, lukisan, patung, kerajinan, benda pakai, senjata (Koentjaraningrat, 1974). Ketiga wujud kebudayaan di atas, saling terkait satu sama lain.

Budaya juga merupakan respon dari kondisi lingkungan yang mengharuskan suatu kelompok masyarakat beradaptasi dan bertahan hidup di wilayahnya. Budaya setempat atau yang biasa disebut dengan local wisdom merupakan akar dari kondisi yang saat ini dapat 'terbaca' di lingkungan fisik dan non fisik masyarakat.

Menurut Andreas Eppink, kebudayaan mengandung keseluruhan pengertian nilai sosial,norma sosial, ilmu pengetahuan serta keseluruhan struktur-struktur sosial, religius, dan lain-lain, tambahan lagi segala

PAWON: Jurnal Arsitektur, Nomor 01 Volume IV, Bulan Januari-Juni Tahun 2020, ISSN 2597-7636 
pernyataan intelektual dan artistik yang menjadi ciri khas suatu masyarakat. Menurut Edward Burnett Tylor, kebudayaan merupakan keseluruhan yang kompleks, yang di dalamnya terkandung pengetahuan, kepercayaan, kesenian, moral, hukum, adat istiadat, dan kemampuan-kemampuan lain yang didapat seseorang sebagai anggota masyarakat.

Etika lingkungan hidup adalah kaidah, norma atau aturan perilaku praktis manusia dalam mengusahakan terwujudnya moral lingkungan, kaidah norma atau aturan ini sesungguhnya ingin mengungkapkan, menjaga dan melestarikan nilai tertentu, yaitu apa yang dianggap baik dan penting oleh masyarakat tersebut untuk dikejar dalam hidup ini. Dengan demikian, etika juga berisikan nilai-nilai dan prinsip-prinsip moral yang harus dijadikan pegangan dalam menuntun perilaku manusia terkait interaksinya dengan lingkungan alamnya. Terdapat beberapa etika lingkungan hidup, yaitu Antroposentrisme, Biosentrisme, Ekosentrisme, Teosentrisme dan Ekofemisme.

\section{METODE PENELITIAN}

Metode yang dipakai dalam penelitian ini adalah deskriptif kualitatif dimana data dibedakan menjadi 2 (dua) yaitu: data primer dan data sekunder. Data primer adalah data yang diperoleh langsung di lapangan, sedangkan data sekunder adalah data yang melengkapi data primer yang diperoleh dari instansi terkait berupa buku/dokumen/catatan yang diteliti atau suatu hasil penelitian.

Untuk mendapatkan data yang tepat dan dapat mendukung proses analisis, maka ada beberapa hal yang perlu diperhatikan dalam pengambilan data, yaitu: menentukan faktor pengaruh, menentukan jenis data apa yang dibutuhkan, menentukan sumber-sumber data yang relevan, menentukan cara mendapatkan data dan alat yang digunakan untuk mendapatkan data tersebut.

Pengambilan data fisik obyek penelitian dilakukan dengan cara mendokumentasikan dengan menggunakan kamera/video, sedangkan untuk pengukuran luas dan ketinggian bangunan, jarak antar bangunan, ruangruang dalam bangunan digunakan roll meter yang direkam dalam tabel dan diolah dalam aplikasi exel, serta sketsa tata ruang pada setiap hunian yang diteliti pada papan sketsa dan kertas gambar (milimeter). Untuk menggali informasi terkait dengan termal, sensasi yang dirasakan penghuni dan aparat yang berwenang direkam dengan alat perekam dan kertas tulis. Guna mendapatkan hasil valid dari posisi dan orientasi massa digunakan kompas yang nantinya akan di croskan dengan data arah angin dan kecepatannya. 


\section{HASIL DAN PEMBAHASAN}

Aktivitas sehari-hari warga sebagian besar berada di sawah. Berdasarkan hasil pengamatan di Desa Belung Kec. Poncokusumo sebagian besar mata pencaharian warga yaitu sebagai buruh tani dengan presentase $40 \%$ sedangkan mata pencaharian warga sebagai pegawai swasta berada di urutan kedua dengan presentase $20 \%$ lalu mata pencaharian warga pegawai negeri sipil berada di urutan ketiga dengan presentase $10 \%$ sama seperti ibu rumah tangga dengan presentase $10 \%$.

Kondisi tersebut menyebabkan anggota keluarga dapat berkumpul pada pagi dan sore hari. Pagi hari mereka berkumpul sebelum berangkat bekerja, sedangkan sore hari mereka berkumpul sepulang dari beraktifitas di luar rumah. Minimnya waktu yang tersedia membuat mereka kerap kali memanfaatkan waktu berkumpul pada saat beraktifitas sambil menikmati makan sarapan dan makan sore atau malam. Sembari menunggu makanan siap dihidangkan mereka seringkali berkumpul dan mengobrol di dalam ruang dapur.

Hal ini yang membuat ruang dapur menjadi ruangan yang paling sering dipergunakan sebagai ruangan untuk berkumpul dan mengobrol. Oleh karena itu tidak heran jika posisi ruangan dapur didekatkan dengan ruangan-ruangan privat keluarga, misalnya ruang tidur. Kondisi tersebut bertujuan agar mudah dijangkau oleh seluruh anggota keluarga.
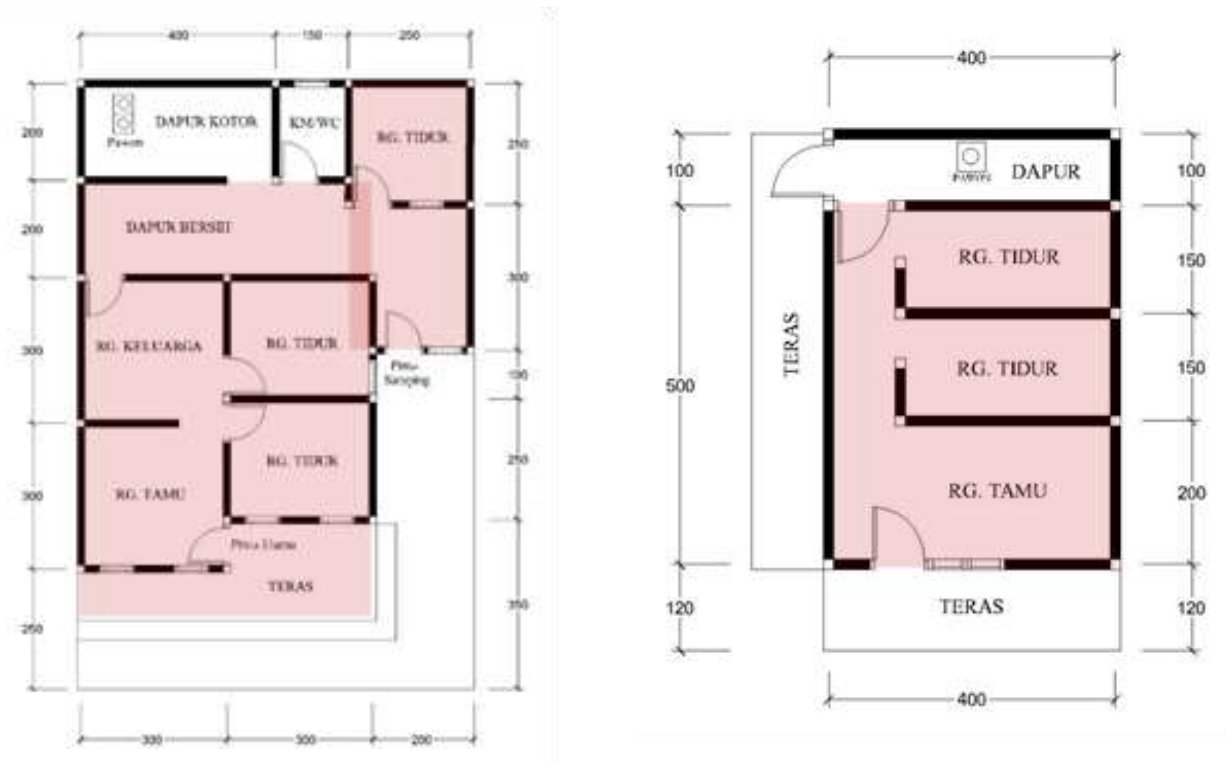

Gambar. 1

Hubungan Ruang Dapur Dengan Ruang Privat Lainnya

Sumber: Analisis Penulis, 2019

PAWON: Jurnal Arsitektur, Nomor 01 Volume IV, Bulan Januari-Juni Tahun 2020, ISSN 2597-7636 
Memanfaatkan ruang dapur sebagai media penghangat sudah menjadi kebiasaan warga sekitar. Melihat kondisi wilayah sekitar yang berudara dingin, tak hayal jika pawon dijadikan sebagai media untuk menghangatkan diri sekaligus menaikan suhu didalam rumah. Mayoritas warga berpendapat jika mereka seringkali menggunakan pawon tersebut untuk menghangatkan diri. Namun sedikit warga yang menggunakannya untuk menurunkan suhu rumah. Mayoritas warga pada dusun ini lebih memilih untuk datang menghampiri sumber panas ketimbang mereka membiarkan energi panas tersebut menyebar keseluruh bagian rumah. Hal ini didasarkan dari polapola ruang yang terbentuk pada rumah warga, yang mana pola tata ruang rumah mereka beberapa diantara nya ada yang membiarkan udara panas dari

Konsep tata ruang dalam seperti rumah di Jawa umumnya yang menganggap bagian dalam rumah adalah sesuatu yang privat, memasuki rumah, bagian depan rumah yaitu bale (bersifat publik, profan dan cahaya cukup terang). Pada bagian lebih dalam yaitu jrumah atau inti rumah, bagian ini hanya bisa diakses oleh penghuni dan kerabat karena sifatnya privat atau orang lain dengan seizin pemilik. Ruang ini gelap tanpa ada pencahayaan alami. Selanjutnya adalah pawon atau dapur dengan sifat ruang servis atau semiprivat, cahaya bisa masuk pada pintu belakang sehingga cukup terang.

Dapur atau pawon merupakan ruang atau alat untuk melangsungkan kegiatan memasak yang sudah ada sejak dahulu yang sampai sekarang masih banyak digunakan dan juga sering dipakai untuk persiapan acara kegiatan budaya yang terkait yaitu selamatan penduduk. Selamatan sebagian besar melibatkan masyarakat skala makro dengan banyak menggunakan ruang luar sebagai tempat ritual (ruang publik) namun pada tahapannya masih tetap menggunakan bagian ruang rumah, yaitu pawon atau dapur untuk menyiapkan makan dengan melibatkan anggota keluarga.

\section{KESIMPULAN}

Mata pencaharian mayoritas warga desa adalah petani. Kearifan lokal akan begitu terasa ketika kita masuk ke wilayah desa ini. Kehidupan seharihari warga tergolong sangat sederhana. Cara berpakaian hingga bentukan rumah merupakan gambaran dari kesederhanaan mereka hidup. Mayoritas warga desa masih mempertahankan adat istiadat khas jawa. Seperti pada kasus penggunaan pawon yang merupakan salah satu tata adat bangunan jawa yang mana mayoritas warga masih menggunakannya. Budaya masyarakat di kawasan permukiman yang masih mengutamakan kondisi kekeluargaan menjadi salah satu aspek non fisik yang menentukan kondisi penataan ruang di dalam sebuah hunian. 


\section{DAFTAR PUSTAKA}

Evans, Martin. 1980. Housing, Climate and Comfort. The Architectural Press. London.

Givoni, B. 1998. Climate Considerations in Building and Urban Design. Van Nostrand Reinhold. New York.

Indeswari, Ayu. 2013. Dinamika Dalam Pemanfaatan Ruang Bersama Pada Perrmukiman Madura Medalungan Di Baran Randugading Malang. Arskon Jurnal Arsitektur dan Konstruksi. Volume 2 No. 1.

Kartono, J. Lukito. 2005. Konsep Ruang Tradisional Jawa Dalam Konteks Budaya. Universitas Kristen Petra Surabaya

Lippsmeier, Georg. 1997. Bangunan Tropis. Penerbit Erlangga. Jakarta

Prijotomo, 1999. Griya Dan Omah, Penelusuran Makna dan Signifikasi di Arsitektur Jawa. Universitas Kristen Petra Surabaya

Rapoport, Amos. 1982. The Meaning of The Built Environment. London

Santosa, M. Nastiti, S. dan Sudarmo, E. 1987. Aspek Kepadatan Dan Bentuk Lingkungan Permukiman pada Penggunaan Energi Alam. Laboratorium Sains Bangunan. Jurusan Arsitektur. ITS. Surabaya.

Sasongko, Ibnu. 2005. Pembentukan Struktur Ruang Permukiman Berbasis Budaya (Studi Kasus: Desa Puyung - Lombok Tengah). Universitas Kristen Petra Surabaya

Van Straaten, JF. 1980. Passive Cooling and Heating Through Building Design. Dalam seminar Passive and Low Energy Cooling, Heating and Dehumidification. University of Miami. Florida.

Waani, Judy O. 2012. Teori Makna Lingkungan Dan Arsitektur. Media Matrasan vol. 9 no. 1. 